\begin{tabular}{|c|c|c|}
\hline Beitr. Ent. & Keltern & ISSN 0005-805X \\
\hline $\mathbf{5 5}(2005) 2$ & S. $289-298$ & 27.12 .2005 \\
\hline
\end{tabular}

\title{
On the Turkish species of Sunius. VI. New micropterous species from central southern Anatolia and additional records
}

\section{(Coleoptera: Staphylinidae, Paederinae)}

With 19 figures and 2 maps

VOLKer Assing

Summary

Three micropterous and apparently locally endemic species of Sunius CurTis, 1829 from central southern Turkey are described and illustrated: S. brevispinosus sp. n. (Kahramanmaraş), S. longispinosus sp. n. (Kahramanmaraş), and S. pauli sp. n. (Malatya). Additional records are presented for two species. The distributions of all the treated species are mapped. 20 species of Sunius are now known from Turkey, including one name of doubtful identity. A supplement to a recent key to the Turkish representatives of the genus is provided.

\section{Keywords}

Coleoptera - Staphylinidae - Paederinae - Sunius - Palaearctic region - Turkey - taxonomy - new species - new records - distribution - endemism

\section{Zusammenfassung}

Drei ungeflügelte und wahrscheinlich lokalendemische Arten der Gattung Sunius CurTis, 1829 werden aus der zentralen Südtürkei beschrieben und abgebildet: S. brevispinosus sp. n. (Kahramanmaraş), S. longispinosus sp. n. (Kahramanmaraş) und $S$. pauli sp. n. (Malatya). Für zwei Arten werden weitere Nachweise aus der Türkei gemeldet. Für alle fünf Arten werden Verbreitungskarten erstellt. 20 Sunius-Arten sind nunmehr aus der Türkei bekannt, darunter ein bisher nicht zu deutender Name. Eine kürzlich erschienene Bestimmungstabelle wird zur Aufnahme der neu beschriebenen Arten ergänzt.

\section{Introduction}

Previously, a total of 17 species of Sunius CuRTis had been recorded from Turkey, including one species of doubtful identity (Assing 1995, 2001, 2003, 2005a, 2005b). Eleven of these species have reduced hind wings and are local endemics. Considering that none of them had been described prior to 2001, it seems most likely that the diversity of Sunius species in Turkey is far greater than presently known and that, among the Staphylinidae, the genus will eventually come in second as regards the number of endemics, exceeded 
only by Geostiba Thomson. That so many species had not been discovered until recently is explained especially by the fact that most of them apparently inhabit the soil of sparsely forested or unforested grass- and shrubland, where they can be collected by sifting the roots of grass and herbs, a habitat rarely studied by previous workers.

Since the last contribution to the Turkish Sunius fauna, more material has become available, most of which was collected during two field trips to central southern Turkey in spring 2005, one of them organised by Volker Brachat (Geretsried) and Heinrich Meybohm (Stelle), and the other by Paul Wunderle (Mönchengladbach) and myself. Not surprisingly, the material yielded another three micropterous Sunius species new to science, as well as additional records of $S$. phasianus (Bordoni) and $S$. dolabrifer Assing. The number of species known from Turkey now amounts to 20 .

\section{Material}

The material examined is deposited in the following collections:

cAss author's private collection

cWun private collection Paul Wunderle, Mönchengladbach

Species descriptions and additional records

Sunius phasianus (BoRdONI) (Map 1)

Additional material examined: Kahramanmaraş: 13 exs., ca. 70 km WNW Kahramanmaraş, N Andırın, NE Çokak, 37 $45 \mathrm{~N}, 36^{\circ} 22 \mathrm{E}, 1540 \mathrm{~m}$, pine and oak litter with grass, sifted, 26.III.2005, leg. Assing, Wunderle (cAss, cWun); 2 exs., 34 km SW Kahramanmaraş, SW Doluca, $37^{\circ} 22 \mathrm{~N}, 36^{\circ} 40 \mathrm{E}, 1250 \mathrm{~m}$, N-slope with oak trees, sifted, 27.III.2005, leg. Assing (cAss).

This species has become known only from Turkey. Its distribution is shown in Map 1.

\section{Sunius dolabrifer Assing (Map 1)}

Additional material examined: Mersin: 2 exs., $\mathrm{N}$ Anamur, road Ermenek-Karaman, $21 \mathrm{~km} \mathrm{~N}$ Ermenek, 3645N, 32 54E, $1620 \mathrm{~m}, 21 . \mathrm{IV} .2005$, leg. Brachat \& Meybohm (cAss). Adıyaman: 1 ex., ca. $50 \mathrm{~km} \mathrm{NE} \mathrm{Adiyaman,} \mathrm{ca.} 5 \mathrm{~km}$ N Sincik, intersection to Serince, $38^{\circ} 03 \mathrm{~N}, 38^{\circ} 36 \mathrm{E}, 1520 \mathrm{~m}$, N-slope with Quercus, Pinus, Cedrus, sifted, 23.III. 2005, leg. Assing (cAss).

Sunius dolabrifer is rather rare and has been recorded only from central southern and southeastern Anatolia (Map 1). 


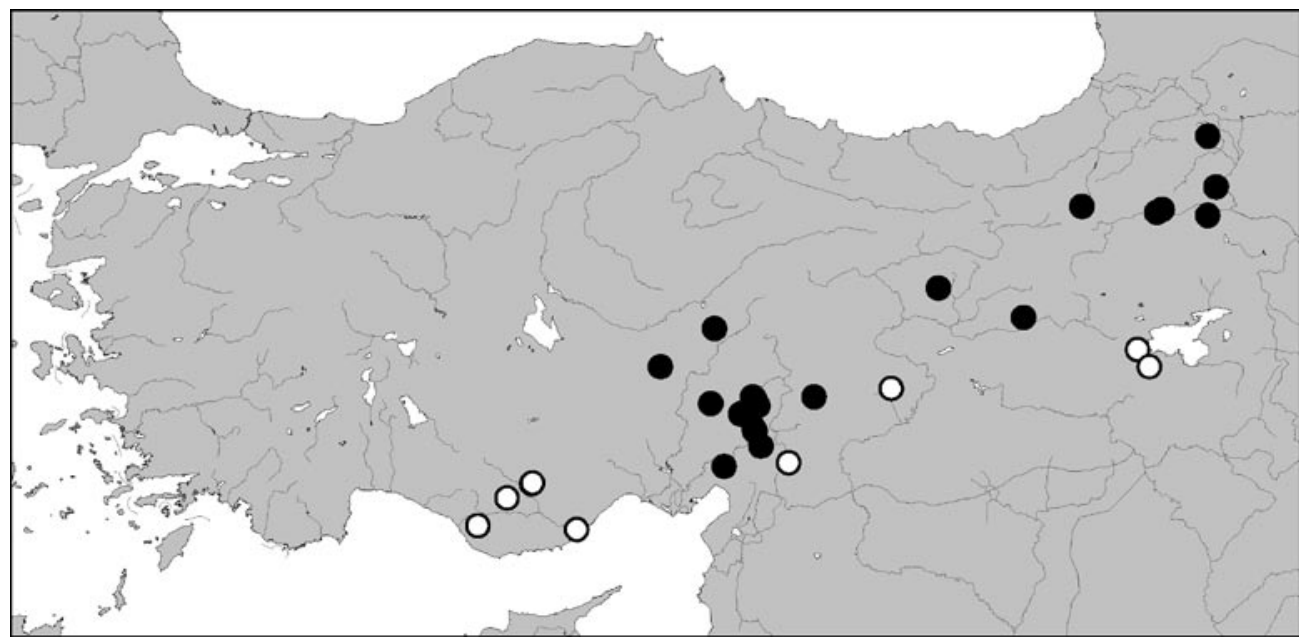

Map 1: Distributions of Sunius phasianus (Bondoni) (filled circles) and S. dolabrifer Assing (open circles) in Turkey, based on examined records.

Sunius brevispinosus sp. n. (Figs. 1-8, 14, Map 2)

\section{Type material:}

Holotype ơ: TR - Kahramanmaraş [31], 25 km SW K. Maraş, Yesilyöre, 600 m, $37^{\circ} 27^{\prime} 18 \mathrm{~N}, 36^{\circ} 46^{\prime} 45 \mathrm{E}, 27$. III.2005, V. Assing / Holotypus ơ Sunius brevispinosus sp. n. det. V. Assing 2005 (cAss). Paratypes: $10^{\star}, 4 \%$ 옹 same data as holotype (cAss); $20^{\star} o^{\star}$, 1 ㅇ: TR - Kahramanmaraş [2], 25 km SW K. Maraş, Yesilyöre, 600 m, 37²7'18N, 36 46'45E, 18.III.2005, V. Assing (cAss); $20^{\star} o^{\star}, 3$ \% $\%$ : same data, but leg. Wunderle (cWun); $20^{\star} o^{*}, 1 \%:$ TR - Kahramanmaraş [1], 20 km SW K. Maraş, Hopurlu env., $560 \mathrm{~m}, 37^{\circ} 28^{\prime} 21 \mathrm{~N}, 36^{\circ} 48^{\prime} 45 \mathrm{E}, 18 . \mathrm{III} .2005$, V. Assing (cAss); $40^{\star} o^{\star}, 2$ ㅇ ㅇ: same data,

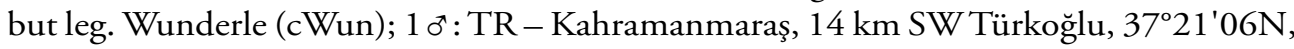
3644'22E, 850 m, 19.IV.2005 [52], Brachat \& Meybohm (cAss).

\section{Description:}

Small species, 2.8-3.3 mm (abdomen extended). Habitus as in Fig. 1. Forebody uniformly reddish yellow, head not darker than pronotum; abdomen of similar colour as forebody or darker; legs and antennae testaceous.

Head weakly oblong, approximately 1.1 times as long as wide (length measured from anterior margin of clypeus; puncturation coarse and well-defined, in central dorsal area sparse, in lateral areas denser; microsculpture absent; eyes small, weakly projecting from lateral outline of head, postocular region in dorsal view approximately 3 times as long as eyes (Fig. 2).

Pronotum approximately 0.95 times as wide as head and 1.15 times as long as wide; microsculpture absent; puncturation variable, usually similar to that of head, though somewhat denser.

Elytra approximately as wide as and at suture about 0.65-0.70 times as long as pronotum; puncturation less well-defined than that of pronotum (Fig. 2); microsculpture indistinct. Hind wings reduced. 


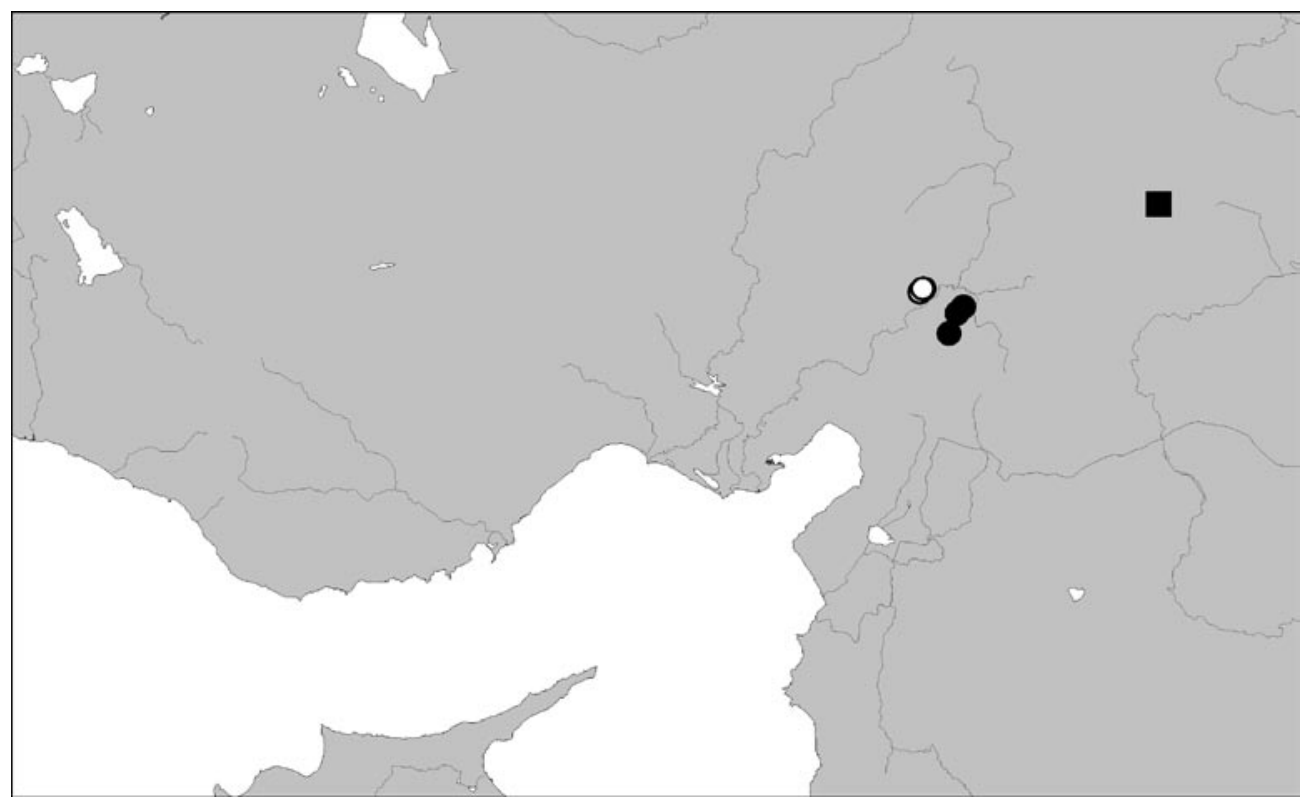

Map 2: Distributions of Sunius brevispinosus sp. n. (filled circles), S. longispinosus sp. n. (open circles), and $S$. pauli sp. n. (square).

Abdomen about 1.1 times as wide as elytra, widest at segments VI-VII; puncturation very fine and moderately dense; microsculpture very shallow on tergites III-VI, somewhat more distinct on posterior tergites; posterior margin of tergite VII without palisade fringe.

$0^{x}$ : sternite VII not distinctly modified (Fig. 8); sternite VIII unmodified, except for the posterior incision; aedeagus of similar general morphology as in the species of the $S$. tuberiventris group, internal sac with a series of relatively short sclerotised spines (Figs. 3-7).

Etymology: The name (Lat., adj.: with short spines) refers to the shape of the spines in the internal sac of the aedeagus, which distinguishes this species from other highly similar congeners.

\section{Comment:}

The internal structures in the aedeagus of the single male collected in the locality southwest of Türkoğlu (19.IV.2005) are slightly longer than those in the males from the other localities. This difference is here attributed to intraspecific variation.

\section{Comparative notes and phylogenetics:}

Sunius brevispinosus belongs to a species group which, in the Eastern Mediterranean, comprises S. amanensis Assıng from the southern Nur Dağları (Antakya), S. hypogaeus (FAUVEL) from Israel, S. renouardi (CoIfFAIT) from Lebanon, and the two following new species. This species group is characterised by small body size, reduced pigmentation (coloration yellowish to reddish yellow), small eyes, reduced hind wings, a male sternite VII without conspicuous modifications, an unmodified male sternite VIII (except posterior incision), and by the synapomorphic presence of a row of sclerotised spines in the internal sac of the aedeagus. From the other species of this species group, S. brevispinosus 
is reliably separated only by the distinctive shape of the spines in the aedeagus. In S. amanensis and the two following new species, these spines are longer, more numerous, and, except for $S$. amanensis, more strongly bent. The aedeagus of $S$. amanensis is figured by Assing (2005b), those of $S$. renouardi and S. hypogaeus by Coiffait (1984).

\section{Distribution and bionomics:}

The type localities are situated in the area to the southwest of Kahramanmaraş, central southern Anatolia. The types were collected by sifting the roots of grass and herbs in the shade of shrubs and trees on slopes with oak and juniper at altitudes of $560-850 \mathrm{~m}$. The locality near Hopurlu is shown in Fig. 14.

Sunius longispinosus sp. n. (Figs. 9-13, Map 2)

Type material:

Holotype ơ: TR [51] - 1450 m, W Kahramanmaraş, Baskonus Yaylası, 5.V.2005, $37^{\circ} 33^{\prime} 32$, 36 $35^{\prime} 21 \mathrm{E}$, Brachat \& Meybohm / Holotypus o Sunius longispinosus sp. n. det. V. Assing 2005 (cAss). Paratypes: $20^{\star} o^{\star}, 1 \%$ : same data as holotype (cAss, cWun); 4 우: TR [50] - $1250 \mathrm{~m}$, W Kahramanmaraş, Baskonus Yaylası, 5.V.2005, $37^{\circ} 33^{\prime} 36,36^{\circ} 33^{\prime} 37 \mathrm{E}$, Brachat \& Meybohm (cAss); $10^{\star}$ [without abdominal apex): TR Karahmanmaras [sic] (24), $30 \mathrm{~km}$ W, $1270 \mathrm{~m}$, Baskonus Yaylasi [sic] / 37³3'58N, 36³4'10E (24), 28.4.2004, leg. Brachat \& Meybohm (cAss); 1 \%: TR Karahmanmaras [sic] (25), $30 \mathrm{~km}$ W, $1500 \mathrm{~m}$, Baskonus Yaylasi [sic] / 37³3'30N, 36³5'12E (25), 28.4.2004, leg. Brachat \& Meybohm (cAss).

\section{Description:}

External characters as in $S$. brevispinosus.

$\sigma^{*}$ : sternite VII similar to that of $S$. brevispinosus, with very weakly concave posterior margin, pubescence weakly modified (Fig. 12); sternite VIII without conspicuous modifications (Fig. 13); aedeagus with row of long and apically curved sclerotised spines in internal sac (Figs. 9-11).

Etymology: The name (Lat., adj.: with long spines) refers to the shape of the spines in the internal sac of the aedeagus.

Comparative notes and systematics:

Sunius longispinosus is distinguished from S. brevispinosus by the longer, more numerous, and apically more strongly curved sclerotised spines in the internal sac and by the slightly more slender apical part (lateral view!) of the ventral process of the aedeagus. For more details see the comparative notes below $S$. brevispinosus.

\section{Distribution and bionomics:}

The restricted distributions of the closely related congeners suggest that S. longispinosus may be locally endemic in the area to the west of Kahramanmaraş. The types were sifted from leaf litter and grass roots between rocks (BRACHAT, pers. comm.) at altitudes of $1250-1500 \mathrm{~m}$. 


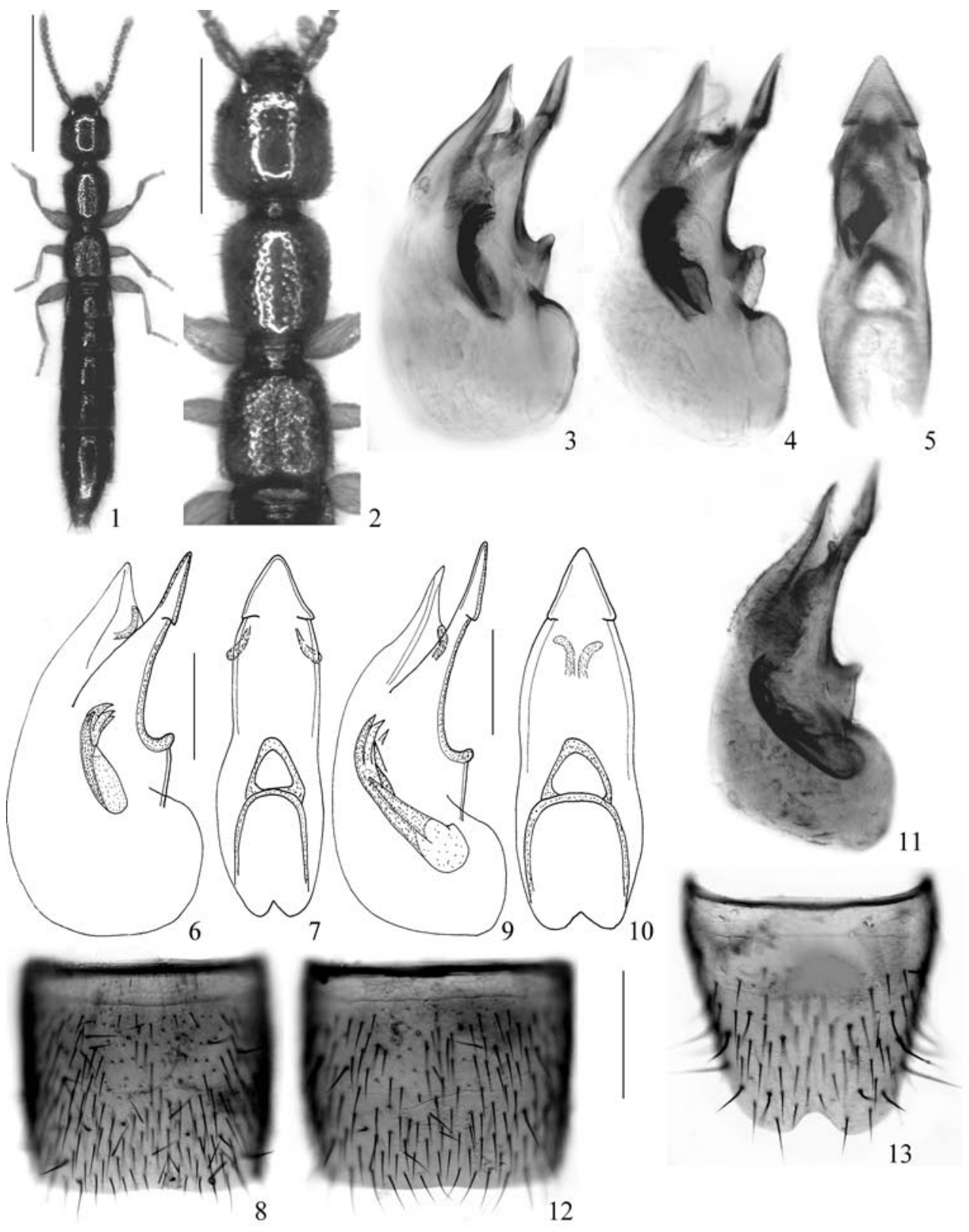

Figs. 1-13: Sunius brevispinosus sp. n. (1-8) and S. longispinosus sp. n. (9-13): habitus (1); forebody (2); aedeagus in lateral and in ventral view $(3-7,9-11)$; ơ sternite VII $(8,12)$; $\sigma^{\dagger}$ sternite VIII $(13)$. Scale bars: 1: $1.0 \mathrm{~mm}$; $2: 0.5 \mathrm{~mm}$; $, 12-13: 0.2 \mathrm{~mm}$; 3-7, 9-11: $0.1 \mathrm{~mm}$. 


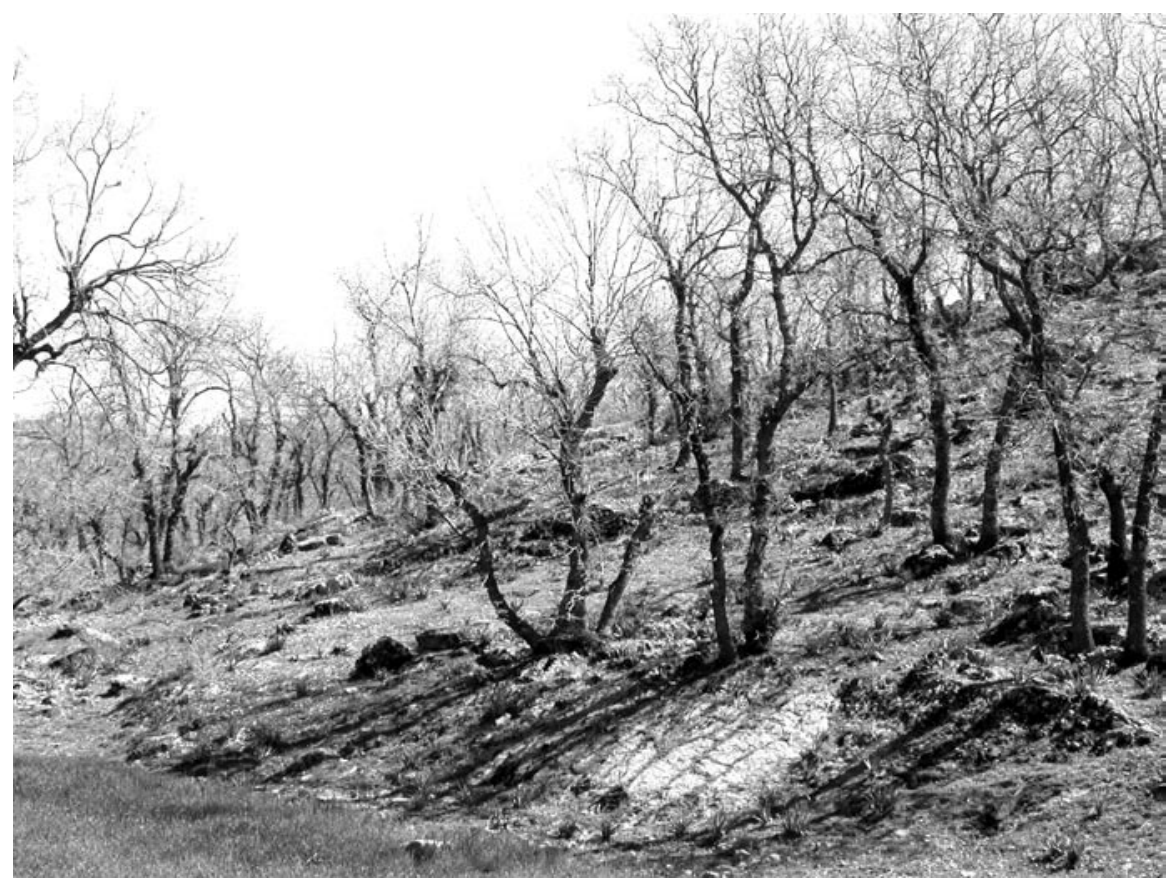

Fig. 14: Type locality of Sunius brevipennis sp. n. (photo by P. WunderLe).

Sunius pauli sp. n. (Figs. 15-19, Map 2)

Type material:

Holotype ơ: TR -Malatya [25], 50 km NW Adıyaman, Reşadiye Geç., $1220 \mathrm{~m}$, 3758'38N, 3800'01E, 25.III.2005, P. Wunderle / Holotypus ơ Sunius pauli sp. n. det. V. Assing 2005 (cAss). Paratypes: 6 우: same data as holotype (cWun, cAss).

\section{Description:}

External characters as in S. brevispinosus.

$\sigma^{*}$ : sternite VII similar to that of $S$. brevispinosus, with very weakly concave posterior margin, pubescence weakly modified; sternite VIII without conspicuous modifications; aedeagus with relatively short and in lateral view rather broad apical part of the ventral process and with row of long sclerotised spines in internal sac, the largest spine with strongly curved apex (Figs. 15-18).

Etymology: The species is dedicated to my friend and colleague Paul Wunderle, who collected the types and to whom I am grateful for the generous gift of the holotype.

\section{Comparative notes and systematics:}

Sunius pauli is distinguished from $S$. brevispinosus and $S$. longispinosus by the apically strongly curved large spine in the internal sac and by the somewhat broader apical part (lateral view!) of the ventral process of the aedeagus. For more details see the comparative notes below $S$. brevispinosus. 

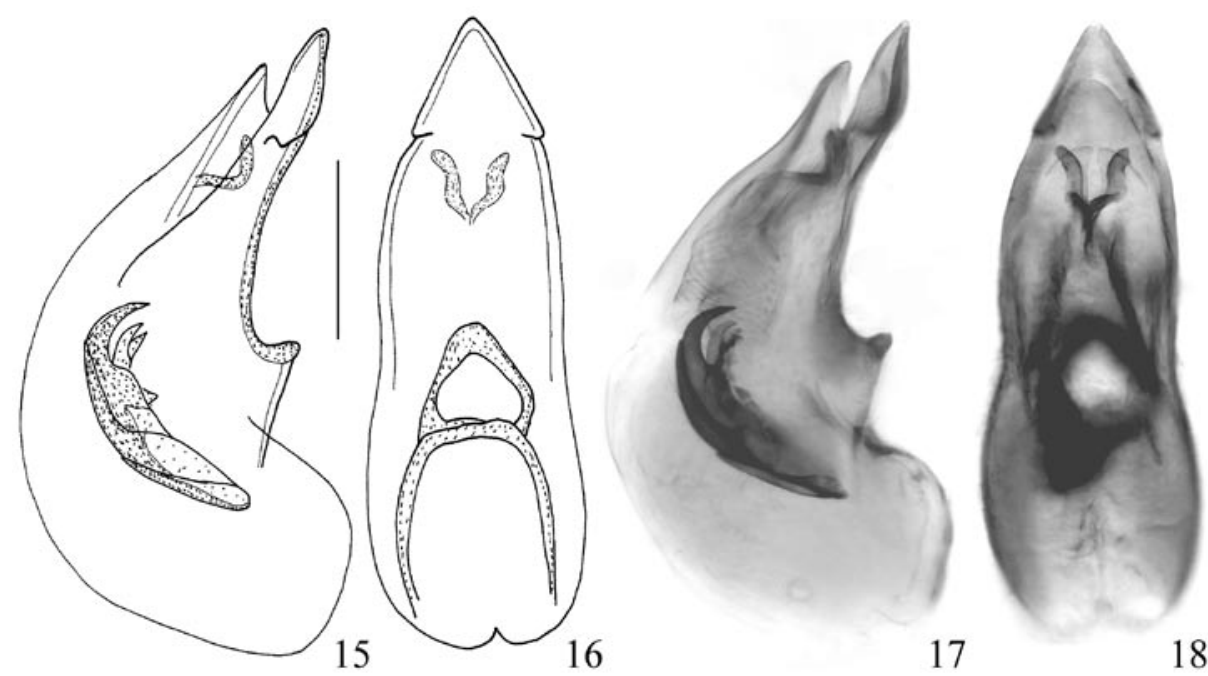

Figs. 15-18: Sunius pauli sp. n.: aedeagus in lateral and in ventral view. Scale bar: $0.1 \mathrm{~mm}$.

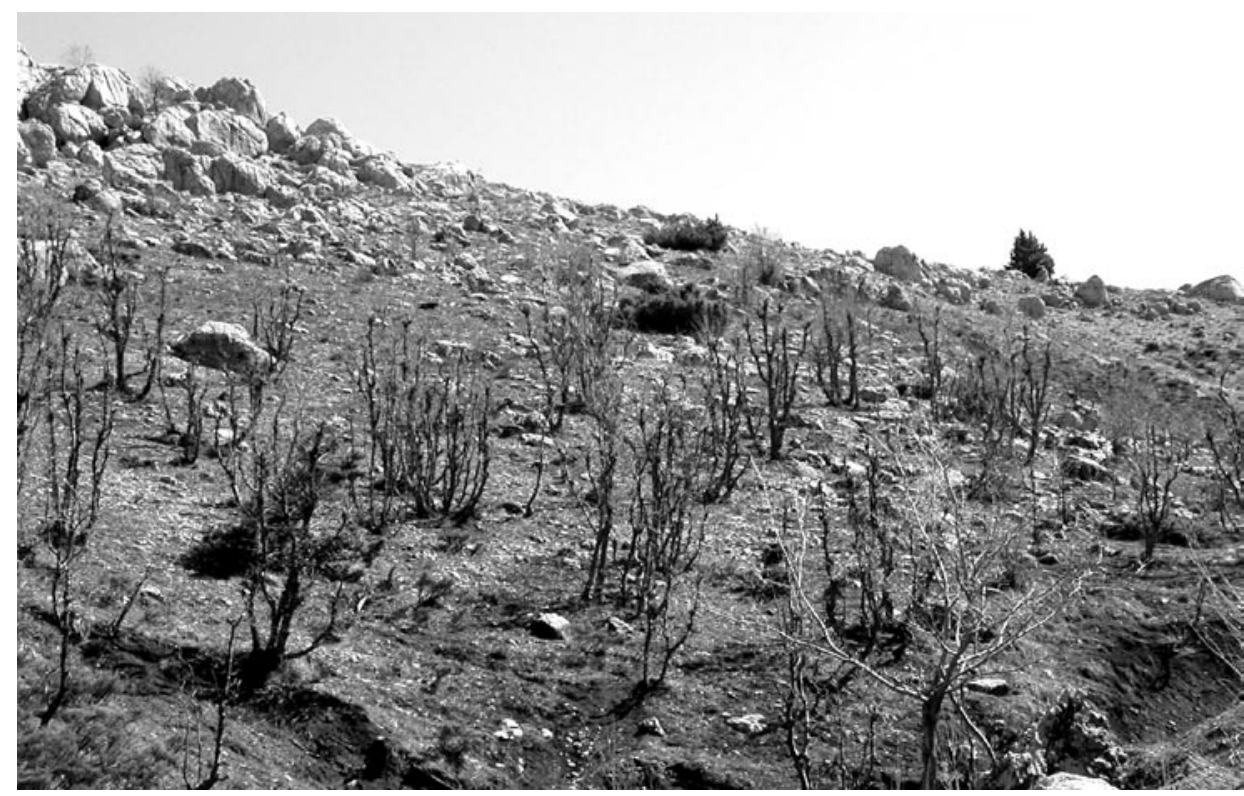

Fig. 19: Type locality of Sunius pauli sp. n. (photo by P. WunderLe).

\section{Distribution and bionomics:}

The type locality is situated in the western part of the Malatya Dağları in the south of Malatya province. The type material was collected by sifting grass and litter between rocks on a north slope at an altitude of $1220 \mathrm{~m}$ (Fig. 19). 


\section{Key to the Turkish species of Sunius: supplement}

Below, a supplement to the key to the Turkish Sunius species in Assing (2005b) is provided. Note that the erroneous reference to couplet 9 in couplet 1 of the original key should be replaced with a reference to couplet 10 . The references to figures in previously published articles are abbreviated as follows: A05a $=$ Assing (2005a); A05b = Assing (2005b).

1. Smaller species, size (normal preparation) usually $<3.4 \mathrm{~mm}$. Head noticeably wider than pronotum. Eyes less than half the length of postgenae in dorsal view. Forebody uniformly ferrugineous or testaceous. Abdominal tergite VII never with palisade fringe at posterior margin. $\sigma^{\star}$ : sternite VII not or only weakly modified; sternite VIII in posterior median area with densely pubescent tubercle, with conspicuous process, or without such modifications. Aedeagus often with spines, but without rod, in internal sac. Southern Anatolia.

- $\quad$ Larger species, body size in normal preparation $>3.0 \mathrm{~mm}$. Head relatively smaller, approximately as wide as or narrower than pronotum. Eyes at least half the length of postgenae in dorsal view, in most species much larger. Forebody in most species bicoloured, with the head darker than the pronotum. Abdominal tergite VII with or without palisade fringe. $\sigma^{*}$ : sternite VII more or less depressed posteriorly, often with darker, stouter, and diagonal pubescence in posterior median area; sternite VIII without tubercle. Aedeagus with long rod-like structure in internal sac. 10

2. $\sigma^{*}$ : sternite VIII without conspicuous modifications. 3

$\sigma^{*}$ : sternite VIII either with distinct spine, tubercle, and/or with patch of tomentose or dense pubescence near posterior emargination.

3. $\sigma^{*}$ : aedeagus with series of distinctly sclerotised spines in internal sac. ....................... 3a

$\sigma^{*}$ : aedeagus without series of distinctly sclerotised spines in internal sac. .................... 4

3a. $\sigma^{*}$ : ventral process of aedeagus in lateral view apically distinctly bent; internal sac of aedeagus with row of 3-4 spines of subequal length (plus smaller spines) (Figs.: A05b: 10-12). Southern Nur Dağları (Antakya).

S. amanensis Assing

$\sigma^{\star}$ : ventral process of aedeagus in lateral view weakly curved at most; internal sac of aedeagus with one or two very large spines and additional distinctly smaller spines. Distribution different. $3 \mathrm{~b}$

3b. $\sigma^{*}$ : apex of ventral process of aedeagus in lateral view not very slender; large spine in internal sac of aedeagus strongly curved (Figs. 15-18). Malatya Dağları (S-Malatya) (Map 2).......

S. pauli sp. n.

$\sigma^{*}$ : apex of ventral process of aedeagus in lateral view slender; large spine in internal sac of aedeagus moderately curved at most. Species from Kahramanmaraş. $3 \mathrm{c}$

3c. $\sigma^{*}$ : sclerotised spines in internal sac shorter (Figs. 3-7). Area to the southwest of Kahramanmaraş (Map 2). S. brevispinosus sp. $\mathrm{n}$. $\sigma^{\star}$ : sclerotised spines in internal sac longer (Figs. 9-11). Area to the west of Kahramanmaraş: Baskonus Yaylası (Map 2). S. longispinosus sp. n.

4. $\sigma^{*}$ : aedeagus subapically not dentate and with relatively short ventral process (Figs. A05a: 23-25). Southwest of Antalya province: Dumanlı Dağı. S. dumanlianus Assing $\sigma^{\star}$ : aedeagus subapically dentate and with longer ventral process (Figs.: A05b: 18-20). Southern Antakya. S. hatayanus Assing 


\section{Acknowledgements}

I am grateful to Volker Brachat (Geretsried) and Heinrich Meybohm (Stelle) for making their staphylinid by-catches from Turkey available to me. Benedikt Feldmann (Münster) proof-read the manuscript.

\section{References}

Assing, V. 1995: Über Sunius fallax (Lokay, 1919) (Col., Staphylinidae). - Entomologische Nachrichten und Berichte 38 (1994): 267-269.

Assing, V. 2001: On the Turkish species of Sunius Curtis 1829 (Coleoptera: Staphylinidae, Paederinae). - Linzer biologische Beiträge 33: 195-210.

Assing, V. 2003: New species and records of Staphylinidae from Turkey (Insecta: Coleoptera: Staphylinidae). - Entomologische Blätter 98 (2002): 153-177.

Assing, V. 2005a: On the Turkish species of Sunius. IV. New micropterous species from southwestern Anatolia and additional records (Coleoptera: Staphylinidae, Paederinae). - Linzer biologische Beiträge 37: 415-423.

Assing, V. 2005b: On the Turkish species of Sunius. V. New species, additional records, a new synonymy, and an updated key to species (Coleoptera: Staphylinidae, Paederinae). - Beiträge zur Entomologie, Keltern 55: 109-121.

CoIfFAIt, H. 1984: Coléoptères Staphylinidae de la région paléarctique occidentale. V. Sous famille Paederinae Tribu Paederini 2, Sous famille Euaesthetinae. - Supplément à la Nouvelle Revue d'Entomologie 13 (4): $1-424$.

\section{Author's address:}

Dr. VOLKer Assing

Gabelsbergerstr. 2

D-30163 Hannover

Germany

e-mail: vassing.hann@t-online.de 